\title{
Dialectical Method and the Critical Political Economy of Culture
}

\author{
Brice Nixon
}

\author{
University of Colorado Boulder, Journalism and Mass Communication, Boulder, USA, \\ brice.nixon@colorado.edu
}

\begin{abstract}
This article argues that the quality that defines critical political economy is its critical method. Definitions of the critical political economy of culture are considered and shown to focus on specific theoretical concerns while not fully addressing the fundamental issue of method. Method is here discussed in terms of the way human reason is used to produce knowledge. A critical method for Marx is a historical materialist dialectical method, thus this paper argues for a deeper consideration of the Marxist dialectical method in relation to critical political-economic theorizing. Sources for methodological consideration from Marx to 20th-century Western Marxists are outlined. The potential contribution of the Marxist dialectical method in the continued development of the critical political economy of culture is demonstrated by showing the possibility of developing a complementary critical political economy of consciousness. Smythe's theorizing of audiences as workers is considered as a useful starting point, and its potential development through incorporation of the work of other critical scholars of media and culture is outlined.
\end{abstract}

Keywords: Critical Political Economy, Dialectical Method, Historical Materialism, Critical Theory, Culture, Consciousness, Marx, Smythe

\section{Introduction}

The critical political economy of culture, communication, media, and information has been defined, examined, and re-examined by a number of eminent political economists over the course of at least four decades. That collective self-reflectivity I take to be a necessary and productive quality of critical theorizing. What does not seem to have been addressed, however - at least not sufficiently is the critical method by which political economy is a critical theory. Critical theory relies on a critical method, and a critical method for Marx is a historical materialist dialectical method. In fact, that method is the foundation of Marx's critical theory. Thus, Marx is an essential source for considering the nature of that method, in addition to being an essential source for the theory and concepts of critical political economy. In this article, I attempt to outline an engagement with the dialectical method that I suggest is necessary for a critical political economy of culture, and I attempt to demonstrate the productive potential of such an engagement by connecting it to the "blindspot" debate about the place of communication in Marxist theory initiated by Smythe (1977). Critical political economy can be a critical theory of the production of culture and the production of consciousness if it is further developed by the Marxist dialectical method.

Marx and a number of Western Marxists developed a historical and materialist dialectical method. By method, I mean a particular use of human reason to produce knowledge of human existence. I follow Marx, Lukács, and Sartre in describing human reasoning as a "method." By historical materialist dialectical method, I mean the use of human reason to produce knowledge of human existence by seeing it as a historical process within a material reality, thereby enabling an understanding of human social being as interrelated and contradictory as it actually is. Such reason is dialectical in that it is "the knowledge and comprehension of man by man" (Sartre 1976, 823); in other words, knowledge and the known, the subject and the object, are dialectically related. Dialectical reason, then, contrasts most clearly with analytical reason, by which knowledge is produced by separating reality into distinct parts. Such reason cannot grasp the whole of human existence because it sees fundamental separations as existing in reality (e.g. "culture" and "economy," "society" and "nature," "mental" and "material"), or, even more fundamentally, asserts an unbridgeable separation of subjective knowledge and objective existence (e.g. Kant 2009). While, as Hegel $(1977,11)$ said of the knowledge produced by dialectical reason, "the True is the whole." For Marx, human existence is both individual and social, differentiated and unified, so any real knowledge of it must be able to see it in that dialectical sense. A dialectical method as employed by Marx (1990, 103 ) is "critical and revolutionary" because it is a means to produce consciousness of the social reality of which every individual is a part but which, as a social reality, is thereby a social product. The dialectical method of reasoning is the means by which Marx produced his own critical thought. 
It is that dialectical method that is the critical foundation of Marx's critical theory, thus I define "critical theory" specifically as theory produced by means of a historical materialist dialectical method, which I also refer to here as a critical or Marxist dialectical method. I do not claim that there is only a subjective, epistemological dialectic - that there is only a dialectical method - and not an objective, ontological dialectic. The method of knowing existence and existence itself cannot be separated in that way if knowledge is to reflect reality ("[T]he dialectic is both a method and a movement in the object" (Sartre 1976, 20). The question I raise in this article is the nature of the method of the critical political economy of culture, an issue within media and cultural studies, not philosophy, thus I do not deal with the dialectic itself. My answer to the question of method is the Marxist dialectical method. Because that critical dialectical method is the critical foundation of Marx's work, it is necessary for political economists who wish to be similarly critical to be self-conscious of their method of theorizing as much as they are self-conscious of their political-economic theory and its concepts so that those concepts, and even the theory itself, do not become static but instead remain perpetually critical. This article is intended to contribute to a consideration of the critical dialectical method of theorizing as it is relevant to critical political economy.

First, I discuss the critical political economy of culture as it has been defined by those who have had a significant role in its development in the late-20th and early-21st centuries. Method in the sense that I define it above does not seem to have played a significant role in defining the critical nature of that political-economic theory, although I note two scholars who have dealt with the critical dialectical method of theorizing culture and communication: Dan Schiller and Christian Fuchs. Next, I examine the role of dialectical method in the work of Marx. I argue Marx's historical and materialist dialectical method is at least as important for the critical political economy of culture as the specifics of his political-economic theory. I then consider the development of the historical materialist dialectical method in the 20th century by Western Marxists who did not attempt to use it as a method of political-economic theorizing but instead as a method of theorizing culture and consciousness. I argue their use of dialectical reasoning to critically understand culture and consciousness is a crucial link between Marx's political economy and the critical political economy of culture and consciousness. Finally, I connect the Marxist dialectical method to the critical political economy of culture by examining the "blindspot" debate and Dallas Smythe's insights into the production of both culture and consciousness.

While the "audience commodity" (Smythe 1977) is an established concept in the critical political economy of culture, the full extent of Smythe's insight seems to have been missed by critical political economists. If the Marxist dialectical method is used more extensively in theorizing culture and, especially, consciousness, the critical political economy of culture can be expanded and developed in a productive way. What I would then call the critical political economy of culture and consciousness can be developed most productively by means of a dialectical method of theorizing as well as an integration of other critical theories (e.g. Horkheimer and Adorno 2002; Williams 1977) and critical histories (e.g. Schiller 1989; 1992) of culture and consciousness. As I hope to make clear in the subsequent sections of this article, a number of previous scholars have already done much to produce the methodological consideration and theoretical development I encourage in this article, and it is only by virtue of their previous efforts that I am able to suggest there is more work to be done in precisely the direction to which they have pointed. This article is primarily aimed at scholars in the area of critical political economy - hence my discussion of the Marxist dialectical method is not comprehensive but rather a sketch of the fundamentals of the method, its intellectual history, and its relevance for the critical political economy of culture - but it is simultaneously intended as a methodological discussion potentially of interest to all scholars of media, communication, and culture. My goal is to make the issue of method a central concern of critical political economy and to demonstrate some of the potential of the historical materialist dialectical method in relation to culture and communication.

\section{Critical Political Economy of Culture: The Problem of Method}

Beginning in the 1970s, a number of scholars contributed to the conscious development of a political economy focused on culture, communication, media, and information. In addition to distinguishing their "political economy" from the dominant neo-classical "economics," those scholars generally defined their approach as "critical." A brief intellectual history of those definitions over more than four decades makes clear the unifying characteristics of that critical political economy. I group them all under the label critical political economy of "culture," although others consider the more appropriate overarching label to be "communication(s)," "(mass) media," or "information." While the continuous efforts to clarify, define, and critique the precise nature of the critical political economy of culture is one of its most productive features - enabling it to follow actual historical change - its 
method does not seem to have received the same attention. Schiller (1996) and Fuchs (2011b), however, have contributed to that latter process. I argue for an engagement with method that is as continuous and widespread as consideration of the theoretical categories and concepts has been.

When "method" has been specifically discussed, it has tended to be techniques of analytical reasoning rather than method in the more fundamental sense of self-conscious critique and declaration of the way in which the human capacity to reason is used to produce "knowledge." In the tradition of Enlightenment thinking, that is what Marx meant by "method," whether discussing his method or that of other political economists or philosophers, and it seems to be equally important for critical political economists of culture to deal with the question of method. Importantly, Marx $(1990,102-103)$ identified his method with the dialectical method of Hegel, which he claims to have modified to make it "critical and revolutionary." By "method," then, I am referring to what can be considered questions of "philosophy," but I do argue that all critical political economists of culture must also be philosophers; rather, it is simply necessary to engage with the work of those who have considered what specifically makes for a "critical" method. Discussions of dialectical method by Marx and Western Marxists are a necessary methodological foundation for a critical political economy of culture. I do not find much evidence of such methodological consideration in the definitions of the critical political economy of culture, and I claim that has had and continues to have important implications for the theory itself. In particular, the production of consciousness has yet to be systematically incorporated as a fundamental aspect of what would then be a critical political economy of culture and consciousness. Instead, the relationship between political economy and consciousness (often under the name "ideology") remains contradictory, and political economists' attempts to resolve that tension threaten the theory with precisely the reification that a critical method is the means to avoid. There are already numerous, though disparate, elements through which a theoretical incorporation of the production of consciousness into critical political-economic theory can be achieved. This article is, in part, an effort to outline what those elements are.

First, I summarize the definitions of the critical political economy of culture offered over the last four decades. Murdock and Golding $(1973,205)$ define the "political economy of mass communications" as an understanding of the "basic features" that "underpin and shape the economic context and political consequences of mass communications." They argue it is necessary to see mass media organizations as "first and foremost" profit-based businesses producing commodities. Media businesses are just like every other capitalist business. But, they are also quite distinct from other industries because of the nature of the commodities they produce: Their products are also ideas objectified into "culture" (e.g. television shows, news stories, music). That dual nature of cultural production through communication media - the products are both "commodities" and "ideas" - is a theme present in all definitions of critical political economy of culture. For Murdock and Golding, the most important task of a political-economic theory is to clarify concretely and specifically how "ideology" is produced (207) by articulating "the general and systematic constraints" generated by media industries' production of culture as a commodity (223). The culture produced is limited by its commodity nature, which creates a general "ideological" effect of reinforcing the status quo (226227). The political economy of "media" is an analysis of the way capitalist power relations are legitimated (232). While Murdock and Golding outline basic theoretical aspects and the recent history that makes such a theory necessary, the issue of method is not addressed.

Garnham (2006/1986) does deal with the critical method of theorizing culture and communication. His complex statement remains an essential foundation of a critical political economy of culture. Most of the article, however, is a discussion of specific theoretical issues, with the dialectical method itself only implicit, although strongly so. Because he stops short of such direct methodological consideration, Garnham fails to completely reject vulgar materialism. While Garnham insightfully critiques exactly the aspects of Marxist theory that must be addressed by a critical political economy of culture (base/superstructure, the means of mental production, ideology, the production of culture), he does not fully resolve the issues he highlights. He relies on a partially reified concept of "the economic" and his political economy of culture is thus also partially reified: Culture can be understood by understanding its historically specific "economic" production. While Garnham repeatedly emphasizes the importance of understanding production historically, his method of theorizing actually de-historicizes the capitalist production of culture and consciousness by taking capitalism at its word and examining production as "economic." While the production of culture cannot be critically theorized that way, the production of consciousness is completely eliminated from consideration. "The economic," is then an "evasion" (Williams 1977, 93; Garnham 2006/1986, 207). Ultimately, Garnham's position is insightful but contradictory, which is what makes his essay a necessary and useful starting point for a critical political economy of culture. 
In critiquing Garnham on those grounds, it might seem as though I am questioning the entire premise of a political economy of culture, but my goal is just the opposite: By arguing that politicaleconomic theory can neither exclude human activity related to "consciousness," "ideology," or "subjectivity," nor consider it something that is understood once "class" and "capital accumulation" are critically theorized (Garnham 2006/1986, 203), I am attempting to expand the terrain of political economy. It seems that the production of culture has been incorporated into the theory in a way that avoids a reductionist "reflection" theory - and that is precisely the contribution of the critical political economy of culture to critical political economy in general - but the production of consciousness remains mostly outside political economy even though consciousness was the first thing Marx (1978d) attempted to show was materially produced.

In one example of the contradictions of the essay, Garnham $(2006 / 1986,206)$ actually articulates that precise issue: "[W]e could say that the purpose of a political economy of culture is to elucidate what Marx and Engels meant in The German Ideology by "control of the means of mental production". But Garnham's critique of Williams reveals a refusal to fully deal with the implications for the critical political economy of culture of "control of the means of mental production": It must also be a critical political economy of consciousness, dealing directly with the problem of "ideology" by means of its own critical method rather than avoiding the problem by proclaiming cultural production a matter of capitalist economics rather than a simple reflection of ruling-class ideology. Again, Garnham is clear in his assertion of the need to see cultural production as the production of commodities and ideas, but the full significance of that production of ideas, which Murdock and Golding $(1973,206)$ also highlight as the aspect of real importance in cultural production, is left unaddressed.

While Williams $(1977 ; 1980 a$; 1980b) pushes for the elimination of all reified methods of theorizing social production by incorporating what he saw as the last significant barrier - culture as material production - Garnham $(2006 / 1986,207)$ pushes back by way of historical specificity and a distinction between "the economic" and "the material". He mistakenly finds Williams to be ignoring the specificity of capitalist production and counters with a reified "economic perspective," while missing the significance of Williams' critique of the method of theorizing. Williams (1977; 1980a; 1980b) demonstrates that, if the concepts and categories of political economy are to remain critical, and if Marxist theory is to remain a critical theory of the social production of human life itself (Marx 1978a, 4 ), the concepts and method of Marx's theorizing must also be used to theorize the production of culture. In contrast to that, Garnham $(2006 / 1986,208)$ makes what is perhaps his most problematic claim: the distinction between "social form" and "cultural form", between which there is "an essential divide". He concludes with the claim that culture and consciousness are not material until "they are translated into social forms". The production of consciousness, and its relationship to culture, is thereby banished from the political economy of culture. There are no grounds for refuting the nowpopular but problematic concept of "immaterial labour", a concept representative of the logical development of the critical theory of culture and consciousness because critically theorizing consciousness has been left to others (Garnham /2011, 41) now signals explicit acceptance of that concept and criticizes its absence from the critical political economy of culture).

Smythe provides the means to reclaim for the critical political economy of culture the space abandoned by Garnham, although Smythe also fails to fully overcome the problems he identifies. Smythe (1977) focuses attention precisely on the production of consciousness by means of the critical dialectical method of Marx. He does not stop at consideration of production by the culture industries but also theorizes audiences as producers rather than consumers. For Smythe, "control of the means of mental production" is in the hands of the "consciousness industry". Members of the audience are forced to work for advertisers, who buy audience labour-power from media companies. Importantly, however, by Smythe's method of theorizing individuals are seen to labour in the production of their own consciousness (and the whole process is seen as social). Smythe does not fully develop his insight to make the critical political economy of culture also a critical political economy of consciousness, but he provides the basic means to do so. He directly addresses the necessity of a dialectical method: "[T]he way to a Marxist theory of how ideology is produced by monopoly capitalism is to use an historical, materialist, dialectical method always seeking the reality of class struggle" (Smythe 1978, 126).

The primary theoretical aspects outlined in the late 1970s have remained the foundation of the critical political economy of culture. Jhally $(1989,66)$ describes it is a theory of "the economic context of ... mass-mediated culture", or what are called "the cultural industries." Like Murdock and Golding, Garnham, and Smythe, Jhally emphasizes the importance of the dual nature of cultural production as commodity production - it produces both commodities for exchange on the market and objects with cultural meaning - and the necessity for the critical political economy of culture to 
account for both. Jhally insightfully claims the Frankfurt School (particularly in "The Culture Industry" (Horkheimer and Adorno, 2002)) is one half of a critical political economy of culture, alongside those more typically identified as political economists (e.g. the scholars discussed in this section). However, Jhally's $(1989,80)$ claim that the exchange-value of cultural commodities dominates the use-value is indicative of the need to further expand the theoretical scope by reconsidering the method of theorizing: While the claim seems to be a simple statement of fact about commodities in a capitalist society, it enables political economists to ignore the use-value, or "meaning", of cultural commodities. The production of culture is thus only partially grasped, since "meaning" is central to the process, and the production of consciousness is again pushed aside as something that can only be understood by other means of theorizing. Critical political economy must be a theory of the production of "meaning" as much as the production of commodities.

More recent definitions of the primary aspects of the critical political economy of culture also echo the earlier definitions (e.g. Garnham 2011; Meehan, Mosco, and Wasko 1993; Mosco 2009; Wasko, Murdock, and Sousa 2011). Meehan, Mosco, and Wasko's $(1993,113)$ discussion of "method" is telling: It makes no reference to the dialectical method of reasoning while claiming use of what it describes as the "analytical" methods of sociology, history, and political economy, including Marx. It is clear the significance and specifics of Marx's dialectical method has been missed. Meehan, Mosco, and Wasko are indeed correct that "a reassessment of method" is necessary (115). In a wide-ranging survey of the specifics of the critical political economy of "communication," Mosco (2009) fills in the details of how scholars have theorized culture, communication, media, and information by the general approach first outlined in the 1970s. However, his relatively brief discussion of the "philosophical foundation" of the theory does not address the dialectical method, and his description of the "critical" epistemology of the theory is telling: Critical is understood in relation to other, presumably uncritical, theories that also have different values (10), rather than the method of reasoning that Marx considers the critical foundation of his political economy. Wasko, Murdock, and Sousa $(2011,1-2)$ define the "critical" aspect of critical political economy similarly - that is, by virtue of the content of the theory rather than the method of theorization. Garnham $(2011,42)$ has recently criticized the field for remaining "stuck with a set of problems and terms of analysis that history has simply passed by", "a tired and narrow orthodoxy". While that critique points directly to problems of method, Garnham instead limits his critique to the concepts and contents of the theory itself. Garnham's political economy of "information" seems to be a move in the wrong direction.

Calabrese $(2004,2)$ agrees with the defining characteristics of a critical political economy of culture outlined by the authors already noted, but he also urges precisely the theoretical development toward which this article is intended to contribute: a deeper engagement with "the production and circulation of meaning" (ibid., 9). He also specifically cites the dialectical method of theorizing as the key to that development (ibid., 9-10). In one sense, then, this article is a contribution further "toward a political economy of culture," a contribution in which the dialectical method is the primary focus.

Two scholars in the field of critical political economy of culture who have dealt with the question of method are Fuchs (2011b) and Schiller (1996). As their considerations of method seem to be exceptions within the field, I highlight them as a necessary starting point for the development of the theory. Fuchs $(2011 b, 97)$ defines a "critical" theory of communication and media similarly to the critical political economists discussed above: "the analysis of media, communication and culture in the context of domination, asymmetrical power relations, exploitation, oppression and control." Importantly, he also specifically insists that "dialectical philosophy" is essential for critical theory in general (ibid., 3-71) and critical media and information studies as an aspect of critical theory (ibid., 112-121). In developing the latter point, Fuchs concentrates on media as technology of communication and thus specifically elaborates on how the critical dialectical method is a means to produce a "complex technology assessment" (ibid., 112) and to see the dialectical relationship between media and society. I focus on culture and consciousness, so I want to expand on his discussion of the critical dialectical method in relation to media and cultural studies by demonstrating the method is useful beyond the avoidance of technological determinism (either optimistic or pessimistic), although that is certainly one necessary use. In terms of a critical theory of culture and consciousness, the critical dialectical method is also a means to critically understand the social production of culture and consciousness. Fuchs also argues for the development of a critical theory of media that integrates approaches that see media as either repressive or emancipatory (ibid., 102, 108, 112), and this article is, in part, an attempt to contribute to that integration.

Schiller (1996) emphasizes Williams' discussions of the critical method of theorizing culture and communication as essential to what he considers a necessary development of a "unified conceptual framework" for theorizing communication. Schiller calls for a framework unified around the con- 
cept of "labour" so that human communication can be understood as an active human process but one that is not separate from other aspects of human social existence. He argues against what he considers to be the theoretical reification of "intellectual labour" as something distinct from "manual labour." While the "dialectical method" is not Schiller's explicit focus, he clearly promotes that critical method of theorizing. Like Fuchs' integrative, dialectical method of theorizing, Schiller's unified approach is a productive way forward in the development of a critical political economy of culture. The method of theorizing culture and communication as production is a historical materialist dialectical method that makes a critical understanding of all human social activity, and the conditions of that activity, the basis of knowledge. By that method, the production of culture and the production of consciousness are the object of a critical political economy of culture and communication. The implications of that method of theorizing will be explored in the final section of this article. First, a deeper engagement with the Marxist dialectical method of theorizing is necessary.

\section{Marx's Dialectical Method: Historical, Materialist, Critical, Revolutionary}

Lukács (1971) argues that method is the essence of Marxism. To be "Marxist", then, is to follow Marx's method rather than to take what he wrote about a capitalist system of production as a definitive, absolute statement. Political economy, then, must be produced by that dialectical method if it is to be similarly critical and revolutionary. The Western Marxists who have explicitly engaged with the dialectical method, however, have not been those working in the area of political economy; they have been those Marxists who went back to the question of method as a way to figure out how to be Marxist without being economistic. The critical political economy of culture that later developed in relation to Western Marxism re-emphasized the importance of the categories of Marxist political economy for understanding culture and communication, but seems to have done so by reiterating Marx's political economy without also engaging with the method that produced it. I follow Lukács in emphasizing the fundamental importance of method, focusing on the method of theorizing. For political economy to be a critical theory, a critical and revolutionary dialectical method is necessary. A critical, revolutionary political economy of culture can only be produced through that same method. In this paper, I attempt to demonstrate what a Marxist dialectical method can contribute to a critical, revolutionary political economy of culture. Marx's dialectical method is the focus of this section. The development of that method by Western Marxists is the focus of the following section.

Marx $(1990,103)$ considers his critique of political economy "critical and revolutionary" by virtue of his dialectical method. It is a critical and revolutionary method because it is not a means to producing thinking that celebrates existing society but is rather a means to produce consciousness of society as a product of human action that is thus historical rather than eternal, and that is thus transformable. The dialectical method, and the theory produced by it, is critical and revolutionary in terms of the consciousness it is a means to produce. For Marx and Marxists, such critical knowledge of society is a necessary means for the social production of a society of freedom and equality. Marx's dialectical method is the foundation of his critique of classical political economy, through which he simultaneously produces his own critical, revolutionary political economy. It enables him to produce knowledge of capitalist society by seeing that society as the product of a social process of production, and to see the nature of that process itself. "Society" is a product, and Marx's critical political economy is a means by which the producers can become conscious of their production; Marx's dialectical method is the means by which he produces that critical political economy:

In its rational form, [the dialectic] is a scandal and an abomination to the bourgeoisie and its doctrinaire spokesmen, because it includes in its positive understanding of what exists a simultaneous recognition of its negation, its inevitable destruction; because it regards every historically developed form as being in a fluid state, in motion, and therefore grasps the transient aspect as well; and because it does not let itself be impressed by anything, being in its very essence critical and revolutionary (Marx 1990, 103).

In a number of his works, Marx critiques the method - the use of reason - of others. It is possible to define Marx's critical, revolutionary dialectical method without seeing it as a specific method for political economy but instead as a means of using human reason in a particular way that can produce knowledge of the world as it is. In Volume I of Capital, Marx (1990) describes what he considers to be the difference between his "materialist" dialectical method and that of Hegel:

My dialectical method is, in its foundations, not only different from the Hegelian, but exactly opposite to it. For Hegel, the process of thinking, which he even transforms into an independent 
subject, under the name of "the Idea," is the creator of the real world, and the real world is only the external appearance of the idea. With me the reverse is true: the ideal is nothing but the material world reflected in the mind of man, and translated into forms of thought. (102)

Marx thereby attempts to establish the materialist basis of his dialectical method: An understanding of the "material" world of humans is the means by which to understand human social existence. The "material" world is, for Marx, the product of human activity but the relationship is dialectical: "circumstances make men just as much as men make circumstances" (Marx, 1978d, 165). Marx (1978b) says a "true materialism" that is a "real science" is one in which the basic principle is "the social relationship 'of man to man,' " (108). Marx (1978c) also says a critical, revolutionary materialism conceives reality as "human sensuous activity, practice" (143). That materialist method is a dialectical method that sees men as the ones "who change circumstances," although they are then also "products of circumstances" (144). Human "essence," the essence of human existence, is not an individual quality; it is social: It is "the ensemble of the social relations" (145). "Social life is essentially practical"; understanding "human practice" in the material world is the method by which to understand social life (145). That is the materialist aspect of Marx's dialectical method.

Marx (1978b), critiques the method of classical political economy as being, essentially, uncritical and counter-revolutionary. It is a method of producing a consciousness of society that does not see it as fundamentally human-produced and, therefore, does not see it as something that can be changed, certainly not something that should be changed. The consciousness produced is one in which existing society - the essence of it, at least - is understood as natural and eternal. Through that consciousness, human activity reproduces existing society. By virtue of that method of reasoning, political economy inherently sides with the interests of capitalists. That is evident in the categories of classical political economy, which Marx $(1973,104)$ claims are "fixed, immutable, eternal categories" that are supposed to represent eternal relations of production. Thus, classical political economists produce an understanding of bourgeois institutions as natural institutions. "In this they resemble the theologians, who likewise establish two kinds of religion. Every religion which is not theirs is an invention of men, while their own is an emanation from God" (120-121). For political economists, present-day relations "are themselves natural laws independent of the influence of time. They are eternal laws that must always govern society. Thus there has been history, but there is no longer any" (121, emphasis added).

In contrast, Marx (1973, 106, emphasis added) says, "[a]ll that exists, all that lives on land and under water, exists and lives only by some kind of movement. Thus the movement of history produces social relations." Economic categories are ideas produced by humans; they are "historical and transitory products" (110). It is possible, therefore, to produce critical, revolutionary categories and critical, revolutionary political economy. Marx claims his method is a means to produce those kinds of categories and that kind of theory. He describes it as dialectical, material, historical, critical, and revolutionary. Marx's dialectical method is a "materialist" method and a "historical" method, which makes it "critical and revolutionary": It is a means to produce knowledge of the fact that human social activity has produced the world that exists, thus human social activity can produce a different world. In The German Ideology, Marx (1978d) defines the fundamental premises of his method: actual human history, meaning human material social being, or human life, as it is comprehensible to humans. Thus the first premise is "the existence of living human individuals" (149):

The premises from which we begin are not arbitrary ones, not dogmas, but real premises from which abstraction can only be made in the imagination. They are the real individuals, their activity and the material conditions under which they live, both those they find already existing and those produced by their activity (149).

Marx re-emphasizes the premises of his method a number of times $(154,155)$, so it should be clear that the human social process of production that is human life is the foundation of his means of using human reason to understand what is in fact a social totality. It is precisely because that totality is in fact a constantly moving social process of human material activity that Marx asserts it is possible for humans to have knowledge of it. That is the historical aspect of Marx's dialectical method.

While Marx's (1978a) statements about "structure" and "superstructure" in the Preface to A Contribution to the Critique of Political Economy can and have been interpreted as his declaration of the greater importance of the economic "base", they can be understood differently if they are placed in the context of what, in the crucial paragraph, he twice says is the thing in which he is most interested: humans producing their own lives. The absolute centrality of "the material condi- 
tions of life" "served as a guiding thread" for his work (4). In that paragraph, there is a well-worn quotation that I, too, will cite, but I want to draw attention to the prepositional phrase at the start: "In the social production of their life" (4, emphasis added). I argue that is the key part of the statement for Marx, for the reasons I have already tried to make clear in this section. While the entirety of the long paragraph is necessary for a full account of one of the foundational statements of Marx's method, these essential lines are a useful starting point:

In the social production of their life, men enter into definite relations that are indispensable and independent of their will, relations of production which correspond to a definite state of development of their material productive forces. The sum total of these relations of production constitutes the economic structure of society, the real foundation, on which rises a legal and political superstructure and to which correspond definite forms of social consciousness. The mode of production of material life conditions the social, political and intellectual life process in general. It is not the consciousness of men that determines their being, but, on the contrary, their social being that determines their consciousness (4).

I will restrict my comments on that dense statement to a few key points. The "social production" of human life is the crucial concept to grasp in order to see the critical and revolutionary extent of Marx's method. It is not an economic determinism. It is a means to know real human social life. To say social being determines social consciousness is not to say that "the economy" determines everything else; "the economy" is an abstraction that is not inherently critical, while Marx uses "the economic structure of society" as a critical concept to describe something concrete: the social and material conditions in which human existence is produced. That perspective on the "social production" of human life should make clear why, for Marx, political economy was a useful means of producing his own consciousness of that social production: Political economy is the theory of material production. Developing that theory with a critical, revolutionary method - a historical materialist dialectical method - makes it a critical, revolutionary theory, and one that is knowledge of all human production, or all human life, not just "economic" production. That knowledge is what Marx produced with his dialectical method.

Marx's method pushes "political economy" to its limits as an independent "science" because it is a method by which to produce knowledge of all social production, meaning all of human life. In developing his own critical political economy, Marx proceeds "from the premises of political economy" (1978b, 70). He uses the concepts of uncritical, counter-revolutionary political economy as a means to produce a critical, revolutionary theory. To do so, he uses a critical, revolutionary, historical materialist dialectical method. In the Preface to the First Edition of Capital Volume I, Marx $(1990,90)$ describes the essence of that method: "In the analysis of economic forms," the only scientific method available is "[t]he power of abstraction." In the process of living, humans always produce consciousness of their existence: Humans have the capacity to abstract from the totality of social being and analyse that totality by breaking it down into concepts and ideas; they can abstract from a process in which they are actively involved. Historical materialist dialectical reasoning is that production of consciousness in a way that does not see the objective world as separate from the knowledge of it. In fact, the ground of Marx's method is that real "scientific" knowledge is only possible as an aspect of the process of human life itself; knowing is only ever really an aspect of being. Humans have the reasoning capacity to produce such real knowledge by thinking dialectically, but they do not automatically do so simply by existing. Hence, I consider Marx to be the most radical of "radical Enlightenment" thinkers (Israel 2010). Critical dialectical reasoning is the only "scientific" means to produce knowledge of human life because human life cannot be observed in nature or isolated in an experiment since humans cannot be outside human life. The historical materialist dialectical method is a means of producing knowledge from inside the process itself, hence it is also a critical, revolutionary method in the true spirit of the Enlightenment. To produce critical and revolutionary consciousness requires a dialectical method that is "materialist" - having its foundation as human activity - as well as "historical" - viewing human life as an ongoing process. That dialectical method is critical and revolutionary because it is a means to produce knowledge of the truth of human life: Humans socially produce their social existence. "[T]he present society is no solid crystal, but an organism capable of change, and is constantly engaged in a process of change" (Marx, 1990, 93).

\section{Western Marxism: Developing a Critical, Revolutionary, Dialectical Method}

Marx's historical materialist dialectical method was further developed by a number of Western Marxists in reaction to the "Marxism" of the Soviet Union, in which the dialectic became a law of 
nature rather than a human capacity to reason. A re-emphasis on the dialectical method was a means to make Marxist theory critical rather than reified. The Western Marxists I consider - Lukács, Marcuse, Horkheimer, Lefebvre, Sartre, and Williams - did not attempt to produce a method for "political economy" but instead contributed to the on-going production of a "critical theory" of society to demonstrate that the Marxist method is not an "economistic" or "reductionist" means of dealing with the aspects of human life that some have problematically considered part of the "superstructure" that "reflects" or is "determined" by the material "base". A Marxist political economy of culture must necessarily deal with that problem within Marxism, therefore it must deal explicitly with questions of method. This article is meant to be a contribution to that process.

Lukács, Marcuse, Horkheimer, Lefebvre, and Williams all reiterate the historical materialism of Marx's dialectical method; Sartre develops that method itself. Lukács (1971) outlines the basic critical method of theorizing in the Marxist sense. Important to such a critical theory is a "process of abstraction" (6), but that does not mean the theory is divorced from real human history. On the contrary, the method of critical theory is to abstract from history. There is, thus, a dialectical relationship between theory and history within the method. In the case of a critical theory, actual history is the specific source for abstraction. By that method, critical theory moves beyond the "real existence" of facts to their "inner core" (8). At the heart of a dialectical method of theorizing is "the simultaneous recognition and transcendence of immediate appearances" (8). By seeing "the isolated facts of social life as aspects of the historical process" and integrating them "in a totality," critical theory becomes a way to turn "knowledge of the facts" into "knowledge of reality" (8). Theory, as "knowledge of the whole" (Lukács 1971, 10; an indication of the importance of Hegel $(1977,11)$ for the Marxist dialectical method), is a "dialectical conception of totality" that makes it possible "to understand reality as a social process" (13). It is consciousness of existence, a necessary aspect of a conscious existence that is capable of producing a different reality. By that critical and revolutionary method, critical theory is also a theory of social change:

Only when the core of existence stands revealed as a social process can existence be seen as the product, albeit the hitherto unconscious product, of human activity. This activity will be seen in its turn as the element crucial for the transformation of existence (19).

Marcuse (1976) defines the Marxist dialectical method similarly, as the means to reveal existence as a social process so that it can be consciously transformed. By virtue of the method used, the theory produced is "a practical one; praxis does not only come at the end but is already present in the beginning of the theory" (Marcuse 1973, 5). It is a critical, revolutionary theory because it is knowledge that informs real action. Because being is dialectical, it "can only be grasped dialectically" (Marcuse 1976, 16). Humans can understand themselves and the world they create - the social process in its totality - as historical and dialectical because that social totality is historical and dialectical. That social process is human history itself, and it is that material social process for which the method is a means of producing consciousness. "Only because and insofar as the real is historical, it is dialectical; the real can and must be understood through the dialectical method" (19).

What Horkheimer (1972) labels "critical theory" is produced by that same historical materialist dialectical method. It is the method of theorizing that Horkheimer attempts to show differentiates a "critical" theory from a "traditional" theory. In fact, Horkheimer's definitive essay would be more aptly titled, "Traditional and Critical Method". A Marxist theory is a critical theory produced by means of a critical method. A critical dialectical method demands critical theorizing, not static theory. The traditional method of theorizing, on the other hand, produces a theory that is uncritical consciousness of the reality of social being. For traditional theory the basic requirement is "harmony": "all the parts should intermesh thoroughly and without friction" and there should be no contradictions (190). In the traditional method, theory and history are separated. "There is always, on the one hand, the conceptually formulated knowledge and, on the other, the facts to be subsumed under it", and that method of subsumption is called "theoretical explanation" (193). Traditional theory is a theory of the status quo. The reproduction of existing society necessitates uncritical consciousness. Critical theory is inherently a theory of social change: It sees society as a material social process of production by means of its historical materialist dialectical method. It is consciousness that is critical and revolutionary because it can envision "the rational state of society", "a future society as a community of free men" (216-217)

Lefebvre also reiterates the critical and revolutionary aspect of the historical materialist dialectical method. Against the method of "dogmatic," simplified, and "economistic" Stalinist Marxism, Lefebvre (2009) defines a "dialectical" form of materialism that is produced by a critical, revolutionary method. Lefebvre's Dialectical Materialism is a critique of Stalinist "dialectical materialism" as a 
philosophy of Nature, with "the laws of the dialectic" as "the laws of Nature" (1-3). Lefebvre's dialectical materialism can be defined negatively as "opposed to those doctrines which limit human existence, either from without or within, by subordinating it to some external existence or else by reducing it to a one-sided element or partial experience seen as being privileged and definitive" (98). In particular, Lefebvre wants to reinstate "alienation" as a foundational concept, in opposition to the method of dogmatic Marxism that rejects or de-emphasizes it (4). For Lefebvre, the historical materialist dialectical method is a means to produce critical, revolutionary consciousness of "the dialectical movements within the human and social reality" (5).

Dialectical materialism's aim is nothing less than the rational expression of the Praxis, of the actual content of life - and, correlatively, the transformation of the present Praxis into a social practice that is conscious, coherent and free. Its theoretical aim and its practical aim knowledge and creative action - cannot be separated (Lefebvre, 2009, 100).

Like Lefebvre, Sartre attempts to counter a "Marxism" that is produced by a non-dialectical method. Sartre's Search for a Method and Critique of Dialectical Reason develop the Marxist dialectical method itself. For Sartre (1968), "philosophy" is method (5); it is "a method of investigation and explication" (5) to produce consciousness. Soviet "Marxism" separates theory and practice into "pure, fixed knowledge" and "empiricism without principles" (22). "[l]t has ceased to live with history" (29). What Sartre $(1976,27)$ calls "external," "transcendental," or "universal" dialectical materialism is a method of seeing human history as simply an aspect of natural history. For Sartre, that method provides no foundation for the possibility of the truth of human knowledge since the movement of history is in nature, outside of human influence. Instead, Sartre insists, the dialectical method must be historical materialism, in which to live and to know are the same (thinking is "a particular form of human activity") but being is irreducible to thought $(25,33)$. "Knowledge" is itself historical (Sartre 1968, 4), thus, it is socially and materially produced; it is a process of "knowing" (4). The method of "knowing" must also be historical and material: It must be critically dialectical. For Sartre, that is a historical materialist dialectical method that is a "regressive-progressive and analytic-synthetic method" (148), a "heuristic" method that "teaches us something new because it is at once both regressive and progressive" (133). The product is critical, revolutionary consciousness, which makes the method "a social and political weapon" (5).

Although Williams also reiterates Marx's historical materialist dialectical method, he also brings the theoretical discussion back to culture and communication. As with the other Western Marxists discussed in this section, Williams attempts to demonstrate that Marxism is not a theory of mechanical materialism or economic determinism or reductionism. In Marxism and Literature, Williams (1977) insists on understanding communication, culture, and consciousness as materially and socially produced. Underlying the dialectical method for Williams is what he describes as an indissoluble, continuous, material social process. That indissoluble process is the unity of different individual human activities, and all such human activities are material. Williams draws on what is a similarly fundamental concept for Marx (1978b; 1978c; 1978d): human material social activity, or labour.

Williams (1977) specifically questions the usefulness of the concept of "ideology." He recognizes its use by Marx as an effort to push for a dialectical method by critiquing attempts to separate and prioritize "consciousness" or "ideas". Williams argues that Marx sees consciousness "from the beginning as part of the human material social process, and its products in 'ideas' are then as much part of this process as material products themselves" (59-60). The human material social process is an "indissoluble process" that includes consciousness and thought (61). Williams says the concept of "ideology" might be insufficient for the redefinition of the products and processes of social signification that is necessary to reinvigorate Marxist cultural theory (71), and the use of the concept within critical political economy in a way that displaces the process of producing consciousness suggests he is correct.

As Williams makes clear, the problem for a critical dialectical method is precisely how to distinguish aspects of what is actually a whole, continuous social process in order to gain knowledge of that process. The Western Marxists considered here have produced complementary answers to that question. Williams makes his own significant contribution in a way that is directly useful for a critical, revolutionary political economy of culture: The method must be to understand all human activity as material production. Williams (1977) critiques the non-dialectical Marxism that divides the whole social process into material production and mental labour/consciousness/thought/culture, a method that he says results in a position that seems "too materialist," or materialist in a vulgar sense, but is actually not materialist enough (90-92). That form of materialism fails "to understand 
the material character of the production of a cultural order" (93). To overcome that failure, Williams says, it is necessary "to look at our actual productive activities without assuming in advance that only some of them are material" (94). It is in the precise spirit of that statement that a critical political economy of consciousness can be developed by means of a dialectical method.

One development within Western Marxism that represents a major alternative to the historical materialist dialectical method I explore and advocate in this article is the Italian or autonomist tradition of Marxism. Specifically, the autonomist concept of "immaterial labour" (e.g. Lazzarato, n.d.) is a theoretical challenge to what I claim is the necessary development of a critical political economy of culture and consciousness. In one sense, the autonomist method of theorizing immaterial labour is a direct challenge to Williams' "cultural materialism", which I cite as particularly useful for the critical political economy of culture and consciousness. The autonomist method appears to be neither fully dialectical nor fully materialist, since its foundation is that "immaterial" activity is now a basic aspect of human life because of technological change (Terranova 2009). Culture and consciousness are essentially distinct from "material" processes and, thus, cannot be understood by the historical materialist dialectical method. A "non-economic critique of political economy" is now necessary because value "is increasingly becoming social and subjective" (Terranova 2009). The autonomist social factory thesis is that social relations produce economic value (Terranova 2009). While I agree with the need to develop a theory of the subjective and the cultural - I push critical political economy toward culture and consciousness - the autonomist method that makes culture and consciousness only now theoretical objects is problematic. The historical materialist dialectical method provides a means to see the production of both culture and consciousness as productive human activities prior to the development of computer technologies. The concept of immaterial labour appears to be a product of exactly the reification of "intellectual" labour that Schiller (1996) critiques. Terranova (2000) is right to see "cultural" and "affective" activities as labour, and she argues for labour as the fundamental category (e.g. 40). She is also correct that we are all "knowledge workers" (42): Culture and consciousness are basic aspects of all human life. But in seeing such as activities as immaterial labour, she relies on a method that prevents the totality of the social process that is human life from being understood as such. Work processes have not now, abruptly "shifted from the factory to society" (33); Work processes within a capitalist society have always entailed labour outside the strict confines of the factory and every other "workplace," particularly the production of consciousness.

Immaterial labour, however, leads directly away from theorizing advertising as a material production process: Postindustrial business "is focused on the terrain outside of the production process: sales and the relationship with the consumer" (Lazzarato, n.d., emphasis added). Advertising is included among "properly 'immaterial' production" as a relationship between production and consumption. It is precisely that theorization that Smythe $(1977 ; 1978)$ critiques by insisting that the audience labours, thus it is involved in a material process of production. However, Lazzarato (n.d.) also notes that the "production of subjectivity ... becomes directly productive, because the goal of our postindustrial society is to construct the consumer/communicator - and to construct it as 'active.' " That claim highlights the issue of method, since Lazzarato insists in a seemingly materialist way that subjectivity is produced and individuals are active, but he insists the whole process is immaterial. The production of subjectivity - what I call the production of consciousness - is not only "an instrument of social control" but now a "productive," "economic" process. For Lazzarato, reception is "a creative act" and, crucially, the "whole ... social relation" of author-work-audience is productive. That is an argument quite similar to Smythe's. But while Smyth's historical materialist dialectical method leads him to theorize the production of consciousness as an aspect within the totality of material production that had previously been missed, Lazzarato's method leads him to insist that the production of consciousness is a distinct, historically new, immaterial process and that it is a social relation that is productive. Rather than theorizing the productivity of a social relation, it seems more useful to theorize the production of culture (based on an "author-work" relation) and its relationship to the production of consciousness (based on a "work-audience" relation).

\section{Toward a Critical Political Economy of Culture and Consciousness: The Marxist Dialectical Method as Solution}

A number of scholars have made significant contributions toward the development of a critical political economy of culture and consciousness by using a dialectical method of theorizing, and I consider a number of them in this concluding section. Although the production of consciousness has not been explicitly theorized by the theory and concepts of critical political economy, many scholars have cleared the way for the development of a critical political economy of culture and conscious- 
ness. A more in-depth engagement with the Marxist dialectical method should prove productive in the further development of such a critical theory. The production of commodified thinking cannot be left outside the realm of critical political economy if the reification, under the name "ideology," of an active, material, and social human process - the production of consciousness - is to be avoided. The historical materialist dialectical method, rather than a more "vulgar" approach (Meehan 1993), a political economy of information (Garnham 2011) or greater emphasis on the commodification of labour within industrial media production (Mosco 2011), is the necessary way to further develop a critical political economy that includes consciousness.

Smythe's (1977) initial effort to start a debate on the understanding of communication among Western Marxists claims there is a "blindspot" in the method of theorizing: Media have been explained by their "ideological" rather than their economic or political role. Smythe labels it an "idealist" explanation (1) because what he calls the "consciousness industry" has not been theorized as an industry producing commodities. He claims the ideas in media content have been emphasized at the expense of the economic process of production in which media and advertising industries are involved. While Smythe has sometimes been understood as claiming the "ideological" role of media is less significant than it economic role, or even abolishing "the problem of ideological reproduction entirely" (Murdock, 1978, 113), he actually makes a significant contribution to a critical political economy of consciousness, which would not abolish the problem of "ideological reproduction" but rather employ a different method of theorizing that process. Smythe $(1978,126$, emphasis added) insists "the way to a Marxist theory of how ideology is produced by monopoly capitalism is to use an historical, materialist, dialectical method always seeking the reality of class struggle." In this final section, I attempt to demonstrate how a deeper engagement with the Marxist dialectical method enables the further development of a critical political economy of culture and consciousness along the specific lines suggested by Smythe. In doing so, I aim to demonstrate that a critical political economy of consciousness is not a radical step but rather the continued development of the project begun as the critical political economy of culture (outlined in Section 2).

Smythe $(1977 ; 1978 ; 2006 / 1981)$ argues that the product of media supported by advertising is not the content communicated through a specific medium (e.g. newspaper articles, television programs) but rather the audience for that content. The "commodity form of mass-produced advertisersupported communications" is audiences, or more specifically, audience labour-power (1977, 2-3). Media produce audience labourers, meaning the audience "works". The method of theorizing media as producing psychological manipulation ("effects") is not a critical method; the critical - i.e. historical, materialist, dialectical - method of theorizing communication media is to abstract from the real human activity engaged in a process of production under specific conditions. By theorizing audience activity in exactly that critical way, Smythe produces a critical political-economic theory of advertising. Audience members are actively engaged in a process of production; they are not manipulated. But that labour process is controlled by the "consciousness industry", and profit is made from the productive activity of audience members. The audience is a commodity, or, more accurately, its capacity to labour is a commodity produced and sold by media and purchased by advertisers. Audience members do not choose to sell their labour-power, but they work for advertisers nonetheless. The "consciousness industry" is a capitalist industry that profits through the process of people producing their own consciousness, a process in which capital owns both labour-power (audiences) and the means of production (for Smythe, advertisements).

Murdock $(1978,110)$ considers Smythe's argument to be a rejection of Western Marxist media theory and replies that "a critical engagement with western Marxism is still indispensable to the development of a comprehensive and convincing Marxist analysis of mass communications". Murdock is correct, but an engagement with the dialectical method of Western Marxism is at least as important as the theoretical engagement he urges. An engagement with that method enables the integration of Marxist media theories and the further development of, among other things, a critical political economy of culture and consciousness. In the previous two sections, I attempted to outline aspects of that methodological engagement with Marx and Western Marxists. In this conclusion, I make provisional suggestions for a development of Smythe's critical political economy of advertising by outlining the contributions of critical theories and histories of media and culture that can be integrated into Smythe's theory to develop a critical political economy of culture and consciousness.

The audience commodity (audience members as labourers) is a widely used concept in the critical political economy of culture: Since the initial debate sparked by Smythe (Smythe 1977, 1978; 2006/1981; Livant 1979; Murdock 1978), the concept has been re-examined (Jhally and Livant 1986; Meehan 1993) and has more recently been both critiqued (Caraway 2011; Hesmondhalgh 2010) and employed by a number of scholars to critically theorize human activity in relation to the 
Internet (Andrejevic 2002; Fuchs 2009; 2010; 2011a; Lee 2011; Napoli 2010). For the audience commodity to remain a critical concept, however, it must be used in a critical, dialectical method of theorizing. One sign of the potential reification of the concept is the failure to distinguish audience labour from "user-generated content". A number of scholars have used the concept of the audience commodity to examine commodification in relation to online activity but failed to fully see the difference between the labour processes of audience members and Internet users (Caraway 2011; Cohen 2008; Fuchs 2009; 2010; 2011a; Hesmondhalgh 2010; Napoli 2010): Audience members are labourers in the production of consciousness, while Internet users producing user-generated content are labourers in the production of culture. Clearly, Internet users also produce their own consciousness while "consuming" online content (including advertising). Uploading a video online or posting on a social networking site, however, is clearly producing culture. Commodified audience labour is a critical concept specifically with respect to the process of producing consciousness, but in contrast to the audience of mass media, the users of new media produce both consciousness and culture.

Commodification on social networking sites, for example, is not only a matter of generating profit by selling members' labour-power to advertisers; it is also a matter of commodifying the culture produced on the site in the form of intellectual property (e.g. Facebook 2011) and controlling the means of producing culture on the site by determining what activities are possible, even if use of the site itself is free. Thus, the Internet makes more obvious the need to connect the critical political economy of culture to the critical political economy of consciousness. Fuchs (2010, 191-192), in fact, calls attention to the relationship between producing culture and producing consciousness, but he uses the audience commodity to account for both processes. A necessary further development is to critically theorize the specific processes and conditions of producing culture and consciousness, and the relationship between the two.

Williams is essential to that development of a critical political economy of culture and consciousness. He conceptualizes the "means of communication" as "means of production" and theorizes communication and culture as human processes of production (Williams 1980a; 1980b; 1982), providing a way to theorize culture and consciousness through the theory and concepts of critical political economy. Most importantly, human productive activity is at the core of Williams' dialectical method of theorizing: "A society is not fully available for analysis until each of its practices is included" (1980a, 44). Cultural practices are an aspect of "the general social process" (44). Within what Williams $(1980 \mathrm{~b}, 53)$ calls "the whole historical social and material process," by which he means human existence, people produce both their consciousness and culture. In both cases, means of production are combined with labour in a process of production. Echoing Marx (1978e), Williams (1980a, 46-49) insists on theorizing human activities primarily as processes of production rather than consumption, and he says there has been a particular failure to do so with respect to communicative and cultural practices. The significance of media companies is that they control those production processes by turning both the means of production and labour into private property. In the capitalist production of culture, media companies are part of the "culture industry" (Horkheimer and Adorno 2002) owning the means of production (media) and the labour (employees) and producing cultural commodities. The possibility for non-capitalist social cultural production is one of the more significant potentials of the Internet (Benkler 2006): Users' labour-power is not commodified, although their products (culture) often are. In the capitalist production of consciousness, media companies are part of the "consciousness industry" (Smythe 1977), owning the means of production (culture, including advertising) and labour (audiences and Internet users) and producing commodified thinking. Integrating Smythe and Williams, then, allows Horkheimer and Adorno's potential contribution to critical political economy to be better understood.

For Horkheimer and Adorno (2002), the culture industry encloses cultural production and produces commodified culture. Their argument is not a critique of mass culture, however; its real significance is the implication of commodified culture for the production of consciousness. The commodified culture produced by the culture industry is used by those who consume it - audience members - in the production of consciousness, and the product is commodified consciousness, which is why Horkheimer and Adorno describe the culture produced by the culture industry as advertising for existing society (131-136): It functions in that manner within the active production of consciousness. Rather than "enlightenment", the result of the mass-produced and widely available commodified culture is "mass deception". Horkheimer and Adorno produce a critical theory of consciousness, not just culture, and the development of a critical political economy of culture and consciousness would benefit from incorporating their method of theorizing culture and consciousness. While Smythe demonstrated the role of advertising and media in the production of consciousness, Horkheimer and Adorno use a dialectical method to critically theorize the relationship between cul- 
ture and consciousness and the role of all culture as a means of producing consciousness, so that, e.g., television programs are no less important than the advertisements that accompany them.

Harvey (2002) develops the political-economic concept of "monopoly rent" in relation to cultural production in a way that also seems useful for theorizing consciousness production. He defines monopoly rent as profit produced by the exchange of exclusively controlled private property (94). It is capital accumulation without wage labour. To the extent media companies have exclusive control over audience labour-power as their private property, as Smythe $(1977 ; 1978 ; 2006 / 1981)$ theorizes, they can extract monopoly rent from advertisers who need access to that labour commodity (a fact also noticed by Jhally and Livant $(1986,125)$ and Caraway $(2011,701-702))$. To the extent media companies have exclusive control over culture as their private (intellectual) property, they can also choose to extract monopoly rent from audience members who need access to that cultural commodity (e.g. cable television). To the extent that advertisers purchase specific audience labourpower as private property, they can extract monopoly rent from non-media companies who need access to those specific audiences. But how does the production of culture and consciousness become a human capacity that can be sold as commodified labour-power in the first place? A historical process stands to be revealed, something Smythe $(1977,16-20)$ realized in his initial critique of Marxist media theory, which he concluded with a brief history of the relationship of newspapers and advertising. Harvey (2003) also offers a concept useful in revealing the historical process of capitalist culture and consciousness production: "accumulation by dispossession." In fact, he makes explicit mention of such a process in relation to cultural production (147-148). The accumulation of capital (the accumulation of social power as defined within a capitalist system of production) does not only occur through wage labour processes and market exchanges, but also through dispossession: appropriation, force, and coercion.

Smythe's $(1978,121)$ description of audience labour as "mind slavery" can thus be seen as a critical conceptualization of the forced, unpaid labour of audiences that results from the appropriation of the means of producing culture and consciousness. While Caraway $(2011,701)$ is correct about media companies creating profit by extracting rent from advertisers, he is incorrect in claiming audience labour is therefore not productive labour. Audience workers produce their own consciousness, and the media companies' monopoly ownership of the necessary means of production (culture) and technology (communication media) makes that process one of coerced labour. A process of dispossession, or enclosure, of the means of consciousness production is made apparent. A vast amount of historical analysis of that process has already been done (e.g. McChesney 1993; 2004; Schiller 1989; 1992; 2006/1991).

Herbert Schiller's work can be seen as a necessary critical historical complement to a critical political economy of culture and consciousness. His analysis of processes of "cultural imperialism" (Schiller 1992; 2006/1991) is a history of the cultural aspect of the "new imperialism" that Harvey (2003) claims is dependent on accumulation by dispossession. With respect to cultural production, Schiller $(2006 / 1991,297)$ labels the result of that cultural dispossession "transnational corporate cultural domination." It is a cultural "system of exploitative control of people and resources" (299). As Schiller $(1992,9)$ notes, the international system of cultural imperialism has its historical origins in the dispossession and monopolization of the means of cultural production nationally: In the United States, multiple processes, including "the seizure of as many sites as possible where people potential consumers - congregate have produced a commercially saturated national environment. ... Scarcely a cultural space remains, consequently, that is outside the commercial web." Accumulation by dispossession and monopoly power are not only a matter of international processes; they also occur within a nation, as Smythe's (1977) sketch of U.S. advertising history suggests. Schiller (1989) also specifically suggests global capitalist cultural production has implications for consciousness production, although the implication is an "ideological" effect rather than an active process of production; the critical political economy of consciousness, however, can be developed in connection with the critical political economy and critical history of cultural production. The origin of capitalist culture and consciousness production can be seen - like the origin of capitalist agricultural production (Marx 1990; Wood 2002) - in the enclosure of the means of production. It is through such enclosure that media companies produce audience labourers, as Smythe (1977) originally claimed: The means of consciousness production are turned into private property, making "consumers" out of producers. Audience activity is "productive consumption" (Marx 1990, 290), producing consciousness by consuming commodified culture. And, as Harvey (2003) demonstrates, accumulation by dispossession is a continuing process: In the production of culture and consciousness, the Internet represents an instrument for potentially non-capitalist production (Benkler 2006), necessitating continuous efforts at "digital enclosure" (Andrejevic 2007, 1-4; Meinrath, Losey, and Pickard 2011). Dan Schiller (1999; 2007) and Fuchs (2010) have both analysed that historical pro- 
cess while further developing the critical political economy of culture by means of a historical materialist dialectical method.

Dan Schiller and Fuchs consider the "audience commodity" within their critical political economies. Both use a dialectical method to theorize the production processes within "digital" and "informational" capitalism (Schiller 1999; Fuchs 2010). Schiller $(2007,152)$ analyses the historical process by which "the Web was rapidly colonized and transformed into a new sales instrument." He sees in the history of the Internet an effort by capitalists to remove the independence of activity that the Internet seems to grant by enclosing online activities and commodifying those activities as audience labour through advertising (Schiller 1999, 116-123). Fuchs $(2010,191-192)$ theorizes human activity on the Internet as labour but considers users generating online content as an example of audience labour, failing to distinguish the production of culture from the production of consciousness. Neither Schiller nor Fuchs develops the critical dialectical method to the full extent to which it can be a materialist method for a critical political economy: They do not see the production of consciousness as a material, social process distinct from, but directly related to, the production of culture. Audience labour-power is commodified and made productive in a particular production process: the production of consciousness.

Smythe's theory remains a necessary and useful means of producing a critical, revolutionary political economy in which all human activity is seen as material, social activity in a material, social process of production. Smythe uses a historical materialist dialectical method to produce a theory of media audience "consumption" as an act of production. From that he develops the critical concept of the "audience commodity", or the audience labour-power commodity. He also specifically points to the importance of method in the development of a political economy that is a critical theory: It is necessary to use a historical materialist dialectical method (Smythe 1978, 126). But Smythe does not, ultimately, escape the "idealist" explanation of media and advertising that he critiqued because he does not move completely beyond "ideological" effects to a critical theory of the active social production of consciousness. Still, Smythe provides a means to develop a critical, revolutionary theory of culture and consciousness by emphasizing "labour," or human activity, as the materialist and historical foundation of a dialectical method of theorizing. The way forward for a political economy of culture and consciousness that is materialist all the way through, that is critical and revolutionary, is to first to go back to Smythe and the historical, materialist, dialectical method, the critical and revolutionary method.

The critical political economy of culture and consciousness produced by the Marxist dialectical method makes clear that the fundamental policy issue is control over the means of producing culture and consciousness. Such a critical political economy makes human activity the focus of understanding social processes and the concern is focused on the effect on humanity of having human activities turned into activities to generate profit for capitalists. Capitalist consciousness and cultural production are then not seen as natural. Critical political economy enables us to see what advertising actually is. As Smythe theorizes, it is the production of consciousness turned into a labouring activity for the accumulation of capital. But advertising only exists on top of already commodified culture and consciousness production. It is only because the means of producing consciousness the cultural commons - have been enclosed that cultural production becomes the commodified activity of the culture industry and consciousness production is forced to draw on that commodified culture. When advertising is understood as a way to profit from the basic, perpetual activity of humans producing there own consciousness, it is easier to understand why there is an incentive to put advertising everywhere possible: Every activity in which people "consume" content is an activity that can be turned into what Smythe calls audience labour. "Decommodification" (Esping-Andersen 1990; Vail 2010) seems to be a practical response. Advertising must be understood as an issue of people's ability to think for themselves without having that activity turned into a way to create profit. Policies of decommodification include expanding the availability of public media and simply decreasing the amount of advertising in culture. With regard to the general issue of consciousness production beyond advertising, however, control over the means of production - culture - is also a policy issue. A cultural commons (Benkler 2003a; 2003b; 2006) is then the ideal for culture as the means of consciousness production. Critical political economy makes clear the necessity of policies to prevent "digital feudalism" (Meinrath, Losey, and Pickard 2011) and "digital enclosure" (Andrejevic 2007; Schiller 2007).

The critical political economy of culture and consciousness is a means to develop critical political economy in general, enabling it to be useful in the creation of a reality that is not capitalist by making it theory that is critical, revolutionary "knowledge of reality" (Lukács 1971, 8), of actual history. To achieve that, it is necessary to make explicit the historical specificity of capitalist cultural production, the continued existence of non-capitalist cultural production as well as continued efforts 
to commodify its products or the labour-power of its producers, and the process of consciousness production and its relationship to cultural production. Historical materialist dialectical reasoning is the only way to avoid separating in thought what is in reality related (Calabrese 2004; Peck 2006): The production of culture and consciousness must be understood within the totality of social production, the totality of human existence of which Marx's method is a means of producing knowledge. A Marxist dialectical method is the necessary means to produce a critical political economy of culture and consciousness that is knowledge of the social production of culture and consciousness within the whole dialectical process of human history: humans producing themselves and their society from the means provided by existing society, means which have previously been produced in the same manner. The Marxist dialectical method is a means to unite critical theory with actual human history.

\section{References}

Andrejevic, Mark. 2002. The Work of Being Watched: Interactive Media and the Exploitation of Self-Disclosure. Critical Studies in Media Communication 19 (2): 230-248.

Andrejevic, Mark. 2007. iSpy: Surveillance and Power in the Interactive Era. Lawrence: University Press of Kansas.

Benkler, Yochai. 2003a. The Political Economy of Commons. Upgrade 4 (3): 6-9.

Benkler, Yochai. 2003b. Freedom in the Commons: Towards a Political Economy of Information. Duke Law Journal 52: 1245-1276.

Benkler, Yochai. 2006. The Wealth of Networks: How Social Production Transforms Markets and Freedom. New Haven: Yale University Press.

Calabrese, Andrew. 2004. Toward a Political Economy of Culture. In Toward a Political Economy of Culture: Capitalism and Communication in the Twenty-First Century, edited by Andrew Calabrese and Colin Sparks, 1-12. Lanham: Rowman \& Littlefield.

Caraway, Brett. 2011. Audience Labor in the New Media Environment: A Marxian Revisiting of the Audience Commodity. Media, Culture \& Society 33 (5): 693-708.

Cohen, Nicole S. 2008. The Valorization of Surveillance: Towards a Political Economy of Facebook. Democratic Communiqué 22 (1): 5-22.

Esping-Andersen, Gosta. 1990. De-Commodification in Social Policy. In The Three Worlds of Welfare Capitalism, 35-54. Cambridge: Polity Press.

Facebook. 2011. Statement of Rights and Responsibilities. Accessed February 25, 2012. http://www.facebook.com/legal/terms?ref=pf

Fuchs, Christian. 2009. Information and Communication Technologies and Society: A Contribution to the Critique of the Political Economy of the Internet. European Journal of Communication 24 (1): 69-87.

Fuchs, Christian. 2010. Labor in Informational Capitalism and on the Internet. The Information Society 26 (3): 179-196.

Fuchs, Christian. 2011a. An Alternative View of Privacy on Facebook. Information 2: 140-165.

Fuchs, Christian. 2011b. Foundations of Critical Media and Information Studies. London: Routledge.

Garnham, Nicholas. 2006/1986. Contribution to a Political Economy of Mass-Communication. In Media and Cultural Studies: KeyWorks, edited by Meenakshi Gigi Durham and Douglas M. Kellner, 201-229. Malden: Blackwell Publishing Ltd.

Garnham, Nicholas. 2011. The Political Economy of Communication Revisited. In The Handbook of Political Economy of Communications, edited by Janet Wasko, Graham Murdock, and Helena Sousa, 41-61. West Sussex: Blackwell Publishing Ltd.

Harvey, David. 2002. The Art of Rent: Globalization, Monopoly and the Commodification of Culture. Socialist Register 38 : 93-110. Accessed February 26, 2012. http://socialistregister.com/index.php/srv/article/view/5778/2674

Harvey, David. 2003. Accumulation by Dispossession. In The New Imperialism, 137-182. Oxford: Oxford University Press.

Hegel, G. F. W. 1977. Phenomenology of Spirit. Translated by A. V. Miller. Oxford: Oxford University Press.

Hesmondhalgh, David. 2010. User-Generated Content, Free Labour and the Cultural Industries. ephemera: theory \& politics in organization 10 (3/4): 267-284. Accessed April 30, 2011. http://www.ephemeraweb.org/journal/10-3/103hesmondhalgh.pdf

Horkheimer, Max. 1972. Traditional and Critical Theory. In Critical Theory: Selected Essays, 188-243. New York: Herder and Herder.

Horkheimer, Max and Theodor W. Adorno. 2002. The Culture Industry: Enlightenment as Mass Deception. In Dialectic of Enlightenment: Philosophical Fragments. Edited by Gunzelin Schmid Noerr. Translated by Edmund Jephcott. Stanford: Stanford University Press.

Israel, Jonathan. 2010. A Revolution of the Mind: Radical Enlightenment and the Intellectual Origins of Modern Democracy. Princeton: Princeton University Press.

Jhally, Sut. 1989. The Political Economy of Culture. In Cultural Politics in Contemporary America, edited by lan H. Augus and Sut Jhally, 65-81. New York: Routledge.

Jhally, Sut and Bill Livant. 1986. Watching as Working: The Valorization of Audience Consciousness. Journal of Communication 36 (3): 124-143.

Kant, Immanuel. 2009. Critique of Pure Reason. Translated and Edited by Paul Guyer and Allen W. Wood. Cambridge: Cambridge University Press.

Lazzarato, Maurizio. n.d. Immaterial Labour. Accessed M arch 29, 2012. http://www.generationonline.org/c/fcimmateriallabour3.htm

Lee, Micky. 2011. Google Ads and the Blindspot Debate. Media, Culture \& Society 33 (3): 433-447.

Lefebvre, Henri. 2009. Dialectical Materialism. Translated by John Sturrock. Minneapolis: University of Minnesota Press.

Livant, Bill. 1979. The Audience Commodity: On the "Blindspot" Debate. Canadian Journal of Political and Social Theory 3 (1): $91-106$. 
Lukács, Georg. 1971. History and Class Consciousness: Studies in Marxist Dialectics. Translated by Rodney Livingstone. Cambridge: The MIT Press.

Marcuse, Herbert. 1973. The Foundation of Historical Materialism. In Studies in Critical Philosophy, 1-48. Translated by Joris de Bres. Boston: Beacon Press.

Marcuse, Herbert. 1976. On the Problem of the Dialectic. Telos 27: 12-39.

Marx, Karl. 1973. The Poverty of Philosophy. New York: International Publishers Co., Inc.

Marx, Karl. 1978a. Marx on the History of His Opinions. In The Marx-Engels Reader (2nd Ed), edited by Robert C. Tucker, 36. New York: W. W. Norton \& Company, Inc.

Marx, Karl. 1978b. Economic and Philosophic Manuscripts of 1844. In The Marx-Engels Reader (2nd Ed), edited by Robert C. Tucker, 66-125. New York: W. W. Norton \& Company, Inc.

Marx, Karl. 1978c. Theses on Feuerbach. In The Marx-Engels Reader (2nd Ed), edited by Robert C. Tucker, 143-145. New York: W. W. Norton \& Company, Inc.

Marx, Karl. 1978d. The German Ideology: Part I. In The Marx-Engels Reader (2nd Ed), edited by Robert C. Tucker, 146-200. New York: W. W. Norton \& Company, Inc.

Marx, Karl. 1978e. The Grundrisse. In The Marx-Engels Reader (2nd Ed), edited by Robert C. Tucker, 221-293. New York, NY: W. W. Norton \& Company, Inc.

Marx, K. 1990. Capital: A Critique of Political Economy: Volume I. London: Penguin Books.

McChesney, Robert W. 1993. Telecommunications, Mass Media, and Democracy: The Battle for the Control of U.S. Broadcasting, 1928-1935. New York: Oxford University Press.

McChesney, Robert W. 2004. The Problem of the Media: U.S. Communication Politics in the Twenty-First Century. New York: Monthly Review Press.

Meehan, Eileen. 1993. Commodity Audience, Actual Audience: The Blindspot Debate. In Illuminating the Blindspots: Essays Honoring Dallas W. Smythe, edited by Janet Wasko, Vincent Mosco, and Manjunath Pendakur, 378-397. Norwood: Ablex Publishing Corporation.

Meehan, Eileen R., Vincent Mosco, and Janet Wasko. 1993. Rethinking Political Economy: Change and Continuity. Journal of Communication 43 (4): 105-116.

Meinrath, Sascha D., James W. Losey, and Victor W. Pickard. 2011. Digital Feudalism: Enclosures and Erasures from Digital Rights Management to the Digital Divide. Commlaw Conspectus: Journal of Communications Law and Policy 19: 423-479.

Mosco, Vincent. 2009. The Political Economy of Communication (2nd Ed). Los Angeles: SAGE.

Mosco, Vincent. 2011. The Political Economy of Labor. In The Handbook of Political Economy of Communications, edited by Janet Wasko, Graham Murdock, and Helena Sousa, 358-380. West Sussex: Blackwell Publishing Ltd.

Murdock, Graham. 1978. Blindspots about Western Marxism: A Reply to Dallas Smythe. Canadian Journal of Political and Social Theory 2 (2): 109-127.

Murdock, Graham and Peter Golding. 1973. For a Political Economy of Mass Communications. Socialist Register 10: 205234. Accessed October 7, 2011. http://socialistregister.com/index.php/srv/article/view/5355/2256

Napoli, Philip M. 2010. Revisiting "Mass Communication" and the "Work" of the Audience in the New Media Environment. Media, Culture \& Society 32 (3): 505-516.

Peck, Janice. 2006. Why We Shouldn't Be Bored with the Political Economy Versus Cultural Studies Debate. Cultural Critique 64: 92-126.

Sartre, Jean-Paul. 1968. Search for a Method. Translated by Hazel E. Barnes. New York: Vintage Books.

Sartre, Jean-Paul. 1976. Critique of Dialectical Reason: Volume I: Theory of Practical Ensembles. Edited by Jonathan Reé. Translated by Alan Sheridan-Smith. London: NLB.

Schiller, Dan. 1996. Theorizing Communication: A History. New York: Oxford University Press.

Schiller, Dan. 1999. Digital Capitalism: Networking the Global Market System. Cambridge: The MIT Press.

Schiller, Dan. 2007. How to Think About Information. Urbana: University of Illinois Press.

Schiller, Herbert. 1989. Culture, Inc.: The Corporate Takeover of Public Expression. New York: Oxford University Press.

Schiller, Herbert. 1992. Mass Communications and American Empire (2nd Ed). Boulder: Westview Press.

Schiller, Herbert. 2006/1991. Not Yet the Post-Imperialist Era. In Media and Cultural Studies: KeyWorks, edited by Meenakshi Gigi Durham and Douglas M. Kellner, 295-310. Malden: Blackwell Publishing Ltd.

Smythe, Dallas. 1977. Communications: Blindspot of Western Marxism. Canadian Journal of Political and Social Theory 1 (3): $1-27$.

Smythe, Dallas. 1978. Rejoinder to Graham Murdock. Canadian Journal of Political and Social Theory 2 (2): 120-127.

Smythe, Dallas. 2006/1981. On the Audience Commodity and Its Work. In Media and Cultural Studies: KeyWorks, edited by Meenakshi Gigi Durham and Douglas M. Kellner, 230-256. Malden: Blackwell Publishing Ltd.

Terranova, Tiziana. 2000. Free Labor: Producing Culture for the Digital Economy. Social Text 63: 33-58.

Terranova, Tiziana. 2009. The Internet as Playground and Factory: Prelude Part III (speech). Accessed March 29, 2012. http://vimeo.com/6882379

Vail, John. 2010. Decommodification and Egalitarian Political Economy. Politics and Society 38 (3): 310-346

Wasko, Janet, Graham Murdock, and Helena Sousa. 2011. Introduction: The Political Economy of Communications: Core Concerns and Issues. In The Handbook of Political Economy of Communications, edited by Janet Wasko, Graham Murdock, and Helena Sousa, 1-10. West Sussex: Blackwell Publishing Ltd.

Williams, Raymond. 1977. Marxism and Literature. Oxford: Oxford University Press.

Williams, Raymond. 1980a. Base and Superstructure in Marxist Cultural Theory. In Problems in Materialism and Culture, 31-49. London: Verso.

Williams, Raymond. 1980b. Means of Communication as Means of Production. In Problems in Materialism and Culture, 5063. London: Verso.

Williams, Raymond. 1982. Means of Production. In The Sociology of Culture, 87-118. New York: Schocken Books.

Wood, Ellen Meiksins. 2002. The Origin of Capitalism: A Longer View. London: Verso. 


\section{About the Author}

Brice Nixon

is a Ph.D. candidate in Communication in the Journalism and Mass Communication program at the University of Colorado Boulder. His dissertation concerns the political economy, history, and cultural policy issues of advertising. 